\title{
Increased risk of wasting syndrome in HIV-infected travellers: prospective multicentre study
}

\author{
Hansjakob Furrer ${ }^{1}$, Phil Chan ${ }^{2}$, Rainer Weber ${ }^{3}$, Matthias Egger ${ }^{2}$ and the Swiss HIV Cohort Study ${ }^{\dagger}$ \\ ${ }^{1}$ Ambulatorium für Infektionskrankheiten, Universitätsspital Bern, Bern, Switzerland; ${ }^{2}$ MRC Health Services Research \\ Collaboration, Department of Social Medicine, University of Bristol, Bristol, UK; ${ }^{3}$ Abteilung für Infektionskrankheiten und \\ Spitalhygiene, Universitätsspital Zürich, Zürich, Switzerland
}

\begin{abstract}
HIV-infected patients from moderate regions who travel in tropical countries may experience clinical disease progression due to exposure to bacteria (including mycobacteria), fungi and parasites. In the Swiss HIV Cohort Study we examined the hypothesis that travelling increases the risk of tuberculosis, wasting syndrome, cryptosporidiosis, isosporiasis, cryptococcosis, coccidiomycosis, histoplasmosis and Salmonella septicaemia. A total of 4549 participants were included (in 1988-98) of whom 596 (13.1\%) travelled at least once. During 16800 person-years of follow-up 231 patients developed at least 1 of the diseases of interest. Wasting syndrome was the only diagnosis significantly associated with travelling (hazard ratio $2 \cdot 16,95 \%$ confidence interval 1.09 to $4 \cdot 30$ ). The risk of wasting syndrome ('slim disease') should be taken into account when counselling HIV-infected patients intending to travel in tropical regions.
\end{abstract}

Keywords: HIV infections, travellers, disease progression, opportunistic infections, wasting syndrome, tropics

\section{Introduction}

Travelling in tropical or subtropical regions may affect the health of HIV-infected people from countries with temperate climates (WILSON et al., 1991). HIV-infected travellers may be at higher risk of contracting the conditions that are typically observed in travellers, for example traveller's diarrhoea, and episodes may take a more severe course. The pattern of AIDS-defining events in tropical countries differs from that in countries in moderate climate zones, and the risk of acquiring certain AIDS-defining conditions, most notably 'slim disease' (wasting syndrome) and tuberculosis, may thus be increased among HIV-infected travellers (GRANT et al., 1997). We analysed the Swiss HIV Cohort Study to examine whether travelling in tropical countries increased the risk of progression to certain AIDS-defining conditions.

\section{Methods}

Study design and inclusion criteria

Described in detail clsewhorc (LEDERGRRER et al., 1994) the Swiss HIV Cohort Study is a prospective cohort study based in 7 outpatient clinics. At each 6monthly visit participants are asked whether they had travelled to a tropical or subtropical country. For the present analysis we included participants of Swiss nationality with a CD4+ cell count within 3 months of enrolment and at least 1 follow-up visit. We excluded patients with a history of AIDS (clinical stage C) at baseline and participants who did not belong to 1 of the 3 main transmission groups (intravenous drug misuse, men who have sex with men and heterosexual contact). We examined whether the risk of 8 conditions, tuberculosis, wasting syndrome, cryptosporidiosis, isosporiasis, cryptococcosis, coccidiomycosis, histoplasmosis, or Salmonella septicaemia, was increased in travellers. Wasting syndrome was defined as documented involuntary weight loss ( $>10 \%$ from baseline) combined with either persistent diarrhoea (at least 3 stools of reduced consistency per day for $>30$ days) or fever for $>30$ days without concurrent specific cause. Visits to a tropical or subtropical country were included as a time-dependent covariate in Cox models. This variable assumed the value 0 throughout in patients who never travelled to the tropics. In travellers the variable switched to 1 as soon

Address for correspondence: Dr Matthias Egger, Department of Social Medicine, Canynge Hall, Whiteladies Road, Bristol BS8 2PR, UK; phone +44 (0) 1179287387 , fax +44 (0) 11792872 36, e-mail m.egger@bris.ac.uk

${ }^{\dagger}$ The investigators of the Swiss HIV Cohort Study are listed in the Acknowledgements. as the first journey was recorded in the database. In additional analyses the dummy variable was allowed to increase with each completed journey. We stratified analyses by 3 calendar periods (1988-90, 1991-94 and 1995-98) to allow baseline hazards to vary across periods. All analyses were adjusted for $\mathrm{CD} 4+$ cell count, clinical stage, transmission group and age at registration. Analyses were conducted using Stata software (version 6.0, College Station, Texas, USA). Results are presented as hazard ratios with $95 \%$ confidence interval $(95 \% \mathrm{CI})$.

\section{Results}

A total of 4549 participants were eligible of whom 596 $(13.1 \%)$ had travelled to a tropical or subtropical country; 381 particinants travelled once, 122 twice and 93 travelled at least 3 times, for a total of 1017 journeys. Participants were observed during 16800 person-years (mean 3.69 years). Those who travelled were less likely to be intravenous drug misusers and had higher CD4+ cell counts at baseline (Table 1). Two-hundred and thirtyone paticnts developed at least 1 of the 8 infections of interest, with a total of 248 events recorded during follow-up. There was no statistically significant association of travelling in tropical or subtropical countries with any of these conditions except for wasting syndrome (Table 2). The adjusted hazard ratio for wasting was $2 \cdot 16$ $(95 \%$ CI 1.09 to 4.30$)$. There was no significant association when the 8 conditions were considered as a group (adjusted hazard ratio $1.24,95 \%$ CI 0.81 to 1.89 ). Results were similar in analyses that took the number of journeys into account. The adjusted hazard ratio was $1.10(95 \%$ CI 0.89 to 1.35$)$ per journey for all 8 conditions and $1.37(95 \% \mathrm{CI} 1.02$ to 1.83$)$ per journey for wasting syndrome. Travelling in tropical or subtropical regions was associated with a lower rate of progression to any AIDS-defining event. The adjusted hazard ratio was $0.77(95 \%$ CI 0.63 to 0.96$)$. No significant association was evident for death from all causes (adjusted hazard ratio $0.93,95 \%$ CI 0.79 to $1 \cdot 10$ ).

\section{Discussion}

There is concern that HIV-infected patients travelling in tropical countries may experience clinical disease progression due to exposure to infectious agents, including mycobacteria, fungi and parasites. Based on theoretical considerations and anecdotal or single-centre experiences most authors and expert committees have argued that travelling to tropical countries carries substantial additional risks in HIV-infected travellers (WILSON et al., 1991). We examined this issue in the Swiss HIV Cohort Study, a prospective study with national coverage which includes about $70 \%$ of AIDS cases 
Table 1. Characteristics at baseline of HIV-infected study participants who did, or did not, travel to a tropical or subtropical country (Switzerland, 1988-98)

\begin{tabular}{|c|c|c|c|}
\hline Characteristic & $\begin{array}{l}\text { Travelled } \\
(n=596)\end{array}$ & $\begin{array}{l}\text { Not travelled } \\
(n=3953)\end{array}$ & $P$ \\
\hline Age (years) & $33 \cdot 1(9 \cdot 1)$ & $33 \cdot 2(8 \cdot 8)$ & $0 \cdot 88$ \\
\hline \multicolumn{4}{|l|}{ Gender } \\
\hline Men & $422(70 \cdot 8)$ & $2774(70 \cdot 2)$ & \multirow[t]{2}{*}{$0 \cdot 75$} \\
\hline Women & $174(29 \cdot 2)$ & $1179(29 \cdot 8)$ & \\
\hline \multicolumn{3}{|l|}{ Clinical stage } & \multirow[t]{3}{*}{$<0.0001$} \\
\hline A & $473(79 \cdot 4)$ & $2869(72 \cdot 6)$ & \\
\hline B & $123(20 \cdot 6)$ & $1084(27 \cdot 4)$ & \\
\hline \multicolumn{3}{|l|}{ Transmission group } & \multirow[t]{4}{*}{0.008} \\
\hline Intravenous drug misuse & $188(31 \cdot 5)$ & $1814(45.9)$ & \\
\hline Sex between men & $239(40 \cdot 1)$ & $1214(30 \cdot 7)$ & \\
\hline IIeterosexual contacts & $169(28 \cdot 4)$ & $925(23 \cdot 4)$ & \\
\hline \multicolumn{3}{|l|}{ Year of enrolment } & \multirow[t]{4}{*}{$<0.0001$} \\
\hline $1988-90$ & $305(51 \cdot 2)$ & $1544(39 \cdot 1)$ & \\
\hline $1991-94$ & $200(33.6)$ & $1324(33.5)$ & \\
\hline $1995-98$ & $91(15 \cdot 3)$ & $1085(27 \cdot 4)$ & \\
\hline CD 4 cell count $\left(\times 10^{6} / \mathrm{L}\right)$ & $411(121-861)$ & $361(91-831)$ & 0.0005 \\
\hline
\end{tabular}

Table 2. Relative hazard of Swiss HIV-infected patients developing events associated with travelling to tropical or subtropical countries: results for hypothesized high-risk conditions

\begin{tabular}{lccc} 
& Number of & \multicolumn{2}{c}{ Hazard ratio (95\% confidence interval) } \\
\cline { 3 - 4 } Event & patients & Crude & Adjusted $^{\mathrm{a}}$ \\
\hline Tuberculosis & 99 & $0 \cdot 86(0 \cdot 41-1 \cdot 80)$ & $0 \cdot 90(0 \cdot 43-1 \cdot 90)$ \\
Wasting syndrome & 59 & $2 \cdot 03(1 \cdot 03-4 \cdot 00)$ & $2 \cdot 16(1 \cdot 09-4 \cdot 30)$ \\
Cryptosporidiosis & 57 & $1 \cdot 28(0 \cdot 54-3 \cdot 04)$ & $1 \cdot 35(0 \cdot 56 \cdot 3 \cdot 23)$ \\
Cryptococcosis & 20 & $1 \cdot 12(0 \cdot 25-4 \cdot 94)$ & $0 \cdot 98(0 \cdot 22-4 \cdot 38)$ \\
Salmonella septicaemia & 7 & $1 \cdot 52(0 \cdot 17-13 \cdot 25)$ & $1 \cdot 64(0 \cdot 18-14 \cdot 88)$ \\
Isosporiasis & 4 & $5 \cdot 15(0 \cdot 49-53 \cdot 56)$ & $3 \cdot 39(0 \cdot 32-35 \cdot 60)$ \\
Histoplasmosis & 2 & $7 \cdot 55(0 \cdot 47-121 \cdot 34)$ & $8 \cdot 73(0 \cdot 37-203 \cdot 40)$ \\
Coccidiomycosis & 0 & & -
\end{tabular}

${ }^{2}$ Adjusted for age, $\mathrm{CD} 4+$ cell count at baseline and during follow-up, CDC stage and transmission group.

diagnosed in the country (LEDERGERBER et al., 1994; EGGER et al., 1997). Over 1000 trips were recorded among the 4549 patients included in this analysis, which demonstrates that travel to tropical regions is popular among people with HIV infection.

Visits to tropical countries were associated with a lower risk of progression to AIDS, indicating that travelling is a proxy for good health. This phenomenon is analogous to the 'healthy worker effect' (Fox \& COLLIER, 1976) in occupational epidemiology where selection bias may be introduced in comparisons with the general population by the fact that people who are able to work tend to be healthier. It is noteworthy that the hazard ratios of 7 out of the 8 conditions that we selected a priori were above 1 , although only the association with wasting reached statistical significance. The fact that we were unable to control fully for what may be termed the 'healthy traveller effect' means that our analysis probably underestimates the strength of these associations. Such considerations are difficult to quantify but they underscore that the increased risk of wasting should be of concern. Wasting is a relatively frequent condition in the later stages of HIV infection in industrialized countries (HOOVER et al., 1993) and 'slim disease' is one of the most important AIDS-defining events in many African and other lessdeveloped countries (GRANT et al., 1997).

Our study has a number of limitations. First, it is possible that information on viral load would have allowed us to control for the 'healthy traveller effect'; however, viral load measurements were introduced only recently. Secondly, the information collected on travels is rather crude. No data are available on the destination, the purpose and duration of the journey, or the style of travelling. Backpackers are known to be at higher risk to contract traveller's diarrhoea than business travellers and tourists who stay in hotels that meet international standards (ERICSSON \& DUPONT, 1993). These limitations mean that we are unable to provide estimates of the risk associated with travelling to tropical regions that take these factors into account. Thirdly, tourism in tropical regions may be followed by chronic diarrhoea, weight loss and fever even in immunocompetent people (STEFFEN et al., 1999). About $2 \%$ of travellers with diarrhoea suffer symptoms for more than 1 month after their return and this chronic course is often associated with significant weight loss (ERICSSON \& DUPONT, 1993). Chronic diarrhoea may be due to infection with Giardia intestinalis, Yersinia spp. or Campylobacter spp., or due to metabolic complications such as lactose intolerance. New pathogens, for example Cyclospora cayetanensis or protozod and viruses that are not defined at present, may lead to self-limiting episodes in immunocompetent hosts but to chronic diarrhoea in HIVinfected travellers (THEA et al., 1993; WEBER et al., 1999). The diagnosis of wasting syndrome is based on the presence of chronic fever, weight loss and diarrhoea, after exclusion of specific aetiological agents. This diagnosis could thus have been incorrect if not every possible pathogen was excluded in thorough examinations (WILCOX et al., 1996). Finally, our study excluded patients with AIDS at enrolment and our results cannot be applied to these patients. 
In conclusion, our results underscore the importance of preventive measures to avoid gastrointestinal infections (ERICSSON \& DUPONT, 1993; SIMONS et al., 1999). When counselling HIV-infected patients prophylactic measures against food- and waterborne infections should be discussed in detail, in addition to addressing the possible need for vaccinations and chemoprophylaxis against malaria and, in exceptional cases, against traveller's diarrhoea (DUPONT, 1993). With the advent of potent antiretroviral combination therapies more people with HIV may decide to spend their holidays in tropical regions. The impact of travelling in less-developed countries on adherence to and efficacy of combination therapies should be examined in future studies (COLEBUNDERS et al., 1999).

\section{Acknowledgements}

We are indebted to all patients who participate in the Swiss HIV Cohort Study and to the members of the Swiss HIV Cohort Study: M. Battegay, E. Bernasconi, H. Bucher, Ph. Bürgisser, M. Egger, P. Erb, W. Fierz, M. Flepp, P. Francioli, H. J. Furrer, M. Gorgievski, H. Günthard, P. Grob, B. Hirschel, Th. Klimkait, B. Ledergerber, M. Opravil, F. Paccaud, G. Pantaleo, L. Perrin, J.-C. Piffaretti, M. Rickenbach, C. Rudin, P. Sudre, V. Schiffer, J. Schupbach, A. Telenti, P. Vernazza, Th. Wagels, R. Weber. This study has been funded in the framework of the Swiss HIV Cohort Study, supported by the Swiss National Science Foundation (Grant no. 3345-062041).

\section{References}

Colebunders, R., Nachega, J. \& Van Gompel, A. (1999). Antiretroviral treatment and travel to developing countries. Foumal of Travel Medicine, 6, 27-31.

DuPont, H. L. (1993). Diarrhoeal disease: current concepts and future challenges. Antimicrobial therapy and prophylaxis. Transactions of the Royal Society of Tropical Medicine and Hygiene, 87, supplement 3, 31-34.

Egger, M., Hirschel, B., Francioli, P., Sudre, P., Wirz, M. Flepp, M., Rickenbach, M., Malinverni, R., Vernazza, P. \& Battegay, $M$. (1997). Impact of new antiretroviral combination therapies in HIV infected patients in Switzerland: prospective multicentre study. Swiss HIV Cohort Study. British Medical foumal, 315, 1194-1199.

Ericsson, C. D. \& DuPont, H. L. (1993). Travelers' diarrhea: approaches to prevention and treatments. Clinical Infectious Diseases, 16, 616-626.
Fox, A. J. \& Collier, P. F. (1976). Low mortality rates in industrial cohort studies due to selection for work and survival in the industry. British fournal of Preventive and Social Medicine, 30, 225-230.

Grant, A. D., Djomand, G. \& De Cock, K. M. (1997). Natural history and spectrum of disease in adults with HIV/AIDS in Africa. $A I D S, 11$, supplement $\mathrm{B}, \mathrm{S} 43-\mathrm{S} 54$.

Hoover, D. R., Saah, A. J., Bacellar, H., Phair, J., Detels, R., Anderson, R. \& Kaslow, R. A. (1993). Clinical manifestations of AIDS in the era of Pneumocystis prophylaxis. Multicenter AIDS Cohort Study. New England fournal of Medicine, 329, $1922-1926$.

Ledergerber, B., von Overbeck, J., Egger, M. \& Lüthy, R. (1994). The Swiss HIV cohort study: rationale, organization and selected baseline characteristics. Sozial und Praeventivmedizin, 39, 387-394.

Simons, F. M., Cobelens, F. G. \& Danner, S. A. (1999). Common health problems in HIV-infected travelers to the (sub)tropics. Foumal of Travel Medicine, 6, 71-75.

Steffen, R., Collard, F., Tornieporth, N., Campbell-Forrester, S., Ashley, D., Thompson, S., Mathewson, J. J., Maes, E., Stephenson, B., DuPont, H. L. \& von Sonnenburg, F. (1999). Epidemiology, etiology, and impact of traveler's diarrhea in Jamaica. Fourmal of the American Medical Association, 281, 811-817.

Thea, D. M., Glass, R., Grohmann, G. S., Perriens, J., Ngoy, B., Kapita, B., Atido, U., Mabaluku, M. \& Keusch, G.T. (1993) Prevalence of enteric viruses among hospital patients with AIDS in Kinshasha, Zaire. Transactions of the Royal Society of Tropical Medicine and Hygiene, 87, 263-266.

Weber, R, Ledergerber, B., Zbinden, R., Altwegg, M., Pfyffer, G. E., Spycher, M. A., Briner, J., Kaiser, L., Opravil, M., Meyenberger, C. \& Flepp, M. (1999). Enteric infections and diarrhea in human immunodeficiency virus-infected persons: prospective community-based cohort study. Swiss HIV Cohort Study. Archives of Intermal Medicine, 159, 1473-1480.

Wilcox, C. M., Rabeneck, L. \& Friedman, S. (1996). AGA technical review: malnutrition and cachexia, chronic diarrhea, and hepatobiliary disease in patients with human immunodeficiency virus infection. Gastroenterology, 111, 1724-1752.

Wilson, M. E., von Reyn, C. F. \& Fineberg, H. V. (1991). Infections in HIV-infected travelers: risks and prevention. Annals of Intemal Medicine, 114, 582592.

Received 19 April 2000; revised 13 March 2001; accepted for publication 16 March 2001

\section{Announcements}

\section{FIS 2001}

Eighth Conference of the Federation of Infection Societies

\author{
Manchester, UK \\ 28-30 November 2001
}

For further details contact FIS 2001, Conference Secretariat, Index Communications Meeting Services, Crown House, 28 Winchester Road, Romsey, Hampshire, SO51 8AA, UK; phone +44 (0)1794 511331/2, fax +44 (0)1794511455, e-mail fis.icms@dial.pipex.com

\section{Promoting Growth and Development of Under Fives How to meet the health needs of children in developing countries}

Antwerp, Belgium

28-30 November 2001

For further information contact Daniëlle Ven Melle, Institute of Tropical Medicine, Nationalestraat 155, 2000 Antwerp, Belgium; phone +3232476206 , fax +3232476213 , e-mail dvmelle@itg.be, website www.itg.be/colloq2001 